\title{
Erratum to: Nitrogen-efficient rice cultivars can reduce nitrate pollution
}

\author{
Khalid Rehman Hakeem • Altaf Ahmad • \\ Muhammad Iqbal • Salih Gucel • Munir Ozturk
}

Published online: 27 July 2011

(C) Springer-Verlag 2011

\section{Erratum to: Environ Sci Pollut Res \\ DOI 10.1007/s11356-010-0434-8}

The original article unfortunately contained mistakes.

- Nitrogen Use Efficiency or NUE should read as Nitrogen Efficiency or NE throughout the text (except in Abstract, paragraph 2, line 3 and paragraph 4, line 6), as well as in Table 1 and Fig. 1.

- On page 3 of the original article, paragraph 3, the formula 'NUE =shoot weight/total nitrogen content of shoot' should read as ' $\mathrm{NE}=[$ Biomass accumulation at low $\mathrm{N}$ level/Biomass accumulation at high $\mathrm{N}$ level] $\times 100$ '.

- On page 3 of the original article, 5th paragraph, lines 16-17, "nanomoles $\mathrm{NO}_{2}^{-}$produced per milligram protein per minute" should read as "micromole $\mathrm{NO}_{2}{ }^{-}$produced per gram dry weight per hour".

- On page 3 of the original article, 6th paragraph, lines 15 16 , "micromoles $\mathrm{NO}_{2}{ }^{-}$utilized per milligram protein per hour" should read as "micromole $\mathrm{NO}_{2}^{-}$utilized per gram dry weight per hour."

- On page 3 of the original article, 8th paragraph, lines 10-11, "micromoles $\gamma$-GH formed per milligram protein per minute" should read as "micromoles $\gamma$-GHA formed per gram dry weight per minute."

- On page 4 of the original article, 6th paragraph, lines 34 , the sentence "six cultivars varied from 0.008 to $0.43 \mathrm{mM}$," should read as "six cultivars varied from 0.008 to $0.043 \mathrm{mM}, "$

The online version of the original article can be found at http://dx.doi. org/10.1007/s11356-010-0434-8.

K. R. Hakeem $(\bowtie) \cdot$ A. Ahmad $\cdot$ M. Iqbal

Molecular Ecology Laboratory, Department of Botany,

Faculty of Science, Hamdard University,

New Delhi 110062, India

e-mail: kur.hakeem@gmail.com

M. Iqbal

Department of Plant Production,

College of Food and Agricultural Sciences, King Saud University,

Riyadh, Saudi Arabia

S. Gucel

Environmental Sciences Institute, Near East University,

Nicosia, Cyprus

M. Ozturk

Science Faculty, Botany Department, Ege University,

Izmir, Turkey 